\title{
PET CT imaging in extramedullary hematopoiesis and lung cancer surprise in a case with thalassemia intermedia
}

\author{
Talasemi intermedia olgusunda ekstramedüller hematopoezin PET CT \\ görüntülemesi ve akciğer kanseri sürprizi
}

\author{
Semra Paydaş¹, Özoğul Sargın², Gülfiliz Gönlüşen ${ }^{3}$ \\ 1Department of Oncology, Faculty of Medicine, Çukurova University, Adana, Turkey \\ ${ }^{2}$ Department of Nuclear Medicine, Faculty of Medicine, Çukurova University, Adana, Turkey \\ ${ }^{3}$ Department of Pathology, Faculty of Medicine, Çukurova University, Adana, Turkey
}

\begin{abstract}
Extramedullary hematopoiesis (EMH) is the production of hematopoietic precursors outside the bone marrow cavity, and it causes mass effects according to its localization. Magnetic resonance imaging (MRI) and/or computed tomography (CT) scans are used most commonly to detect EMH foci. We report herein a case with thalassemia intermedia causing paravertebral mass associated with EMH detected by CT scan. We further evaluated the case with positron emission tomography (PET) CT, and lung cancer, which was not revealed in the CT scan, was detected coincidentally.

(Turk J Hematol 2011; 28: 60-2)

Key words: Extramedullary hematopoiesis, PET CT, SUV max

Received: June 7, 2009

Accepted: July 3, 2009

\section{Özet}

Ekstramedüller hematopoez (EMH), hematopoetik öncü hücrelerin kemik iliği dışında üretimidir ve lokalizasyonuna göre kitle etkilerine neden olur. EMH odaklarını saptamada en sık MRI ve/veya CT kullanılır. Biz burada talasemi intermedia'lı bir olguda paravertebral kitleye yol açan ve CT ile saptanan bir EMH olgusu sunduk. PET CT ile daha ileri incelemede, CT ile saptanamamış olan, akciğer kanseri saptand. (Turk J Hematol 2011; 28: 60-2)

Anahtar kelimeler: Ekstramedüller hematopoez, PET CT, SUV max
\end{abstract}

Geliş tarihi: 7 Haziran 2009

Kabul tarihi: 3 Temmuz 2009 


\section{Case}

A 52-year-old male admitted to the hospital for further evaluation of a paravertebral mass. He had been investigated for dyspnea in another center. Thoracic computed tomography (CT) showed paravertebral mass, and fine needle aspiration (FNA) from this mass had been reported as extramedullary hematopoiesis (EMH).

The patient had a history of cigarette smoking (80 pack-years). Splenomegaly had been detected at the age of 20 years; he had no transfusion history. Physical exam showed pallor, icterus, and spleen palpable $7 \mathrm{~cm}$ below the left costal margin.

Abnormal laboratory findings were as follows: $\mathrm{Hb}$ : $8.7 \mathrm{~g} / \mathrm{dl}$, Hct: $30.2 \%$, WBC: $8.5 \times 10^{9} / \mathrm{L}$, platelet: $359 \mathrm{x}$ $10^{9}$ /L, MCV: 62 fl, MCHC: 28, RDW: 29.3, ferritin: 1698, erythrocyte sedimentation rate (ESR): $5 \mathrm{~mm} / \mathrm{h}$, alkaline phosphatase (ALP): 526 IU, uric acid (UA): $8.2 \mathrm{mg} / \mathrm{dl}$, total/direct bilirubin: 1.48/0.19 mg/dl, aspartate/alanine aminotransferase (AST/ALT): 162/275 IU/L, gamma glutamyl transpeptidase (GGT): 307 IU, lactate dehydrogenase (LDH): $649 \mathrm{U}$, HbA1: 53.20\%, HbA2: 8.30\%, HbF: 38.20\%, and HbS: $0 \%$. Bone marrow biopsy showed hypercellularity with erythroid hyperplasia. Written informed consent was obtained from the patient.

Clinical outcome: The patient was evaluated as thalassemia intermedia and paravertebral mass due to the EMH was detected by CT scan. He was further explored for dyspnea and fatigue developing in recent months. Fluorodeoxyglucose positron emission tomography (FDG PET)/CT was performed to evaluate the extramedullary mass and to determine whether there was another focus of the extramedullary mass causing dyspnea. PET/CT showed a paravertebral mass measuring $13 \mathrm{~cm}$ in diameter with regular borders at the posterior-inferior mediastinum, and standardized uptake value (SUV) max of this mass was 2.5. This mass was thought to be benign in origin and was found to be compatible with EMH diagnosed by FNA. However, surprisingly, there was a small subpleural mass (SUV max 13) localized at the latero-basal segment of the lower lobe of the right lung (Figure 1). Due to the very high SUV max value, this mass was evaluated as malignant. The patient's history of smoking also suggested an epithelial neoplasia. FNA biopsy was made

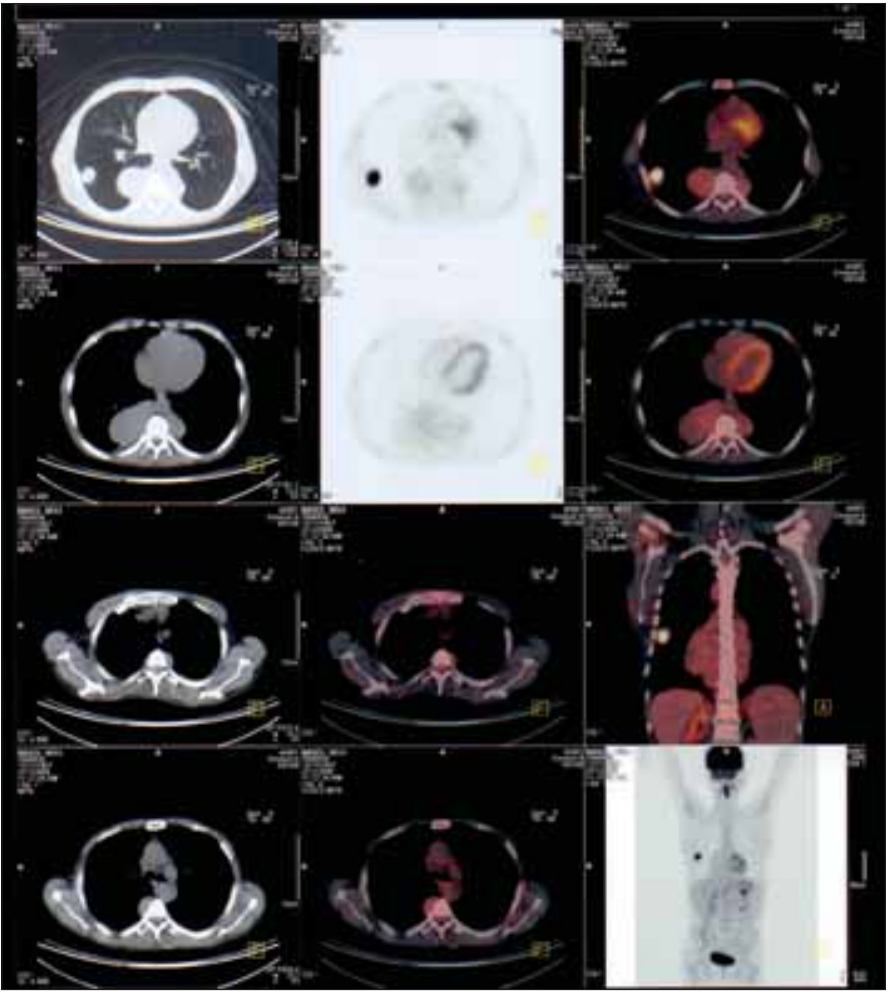

Figure 1. PET CT imaging of extramedullary mass (low SUV max) and coincidental lung cancer (high SUV max)

from this mass, which was reported as non-small cell lung cancer. Surgery was performed for this malignant mass, and T2N0M0 non-small cell lung cancer was detected hitopathologically.

\section{Discussion}

Extramedullary hematopoiesis (EMH) occurs in various disorders and is most commonly seen in sickle cell anemia, thalassemia, hereditary spherocytosis, polycythemia rubra vera, and especially in myelofibrosis. This is a compensatory mechanism for bone marrow dysfunction. The most frequent cause of EMH is thalassemia intermedia, as seen in our case. EMH usually involves the liver, spleen and lymph nodes, and it may cause paravertebral/intrathoracic, intraabdominal or pelvic masses. These foci are generally asymptomatic but may lead to symptomatic tumor-like masses [1,2]. The most commonly used diagnostic methods for EMH are magnetic resonance imaging (MRI) and CT scans [3-5]. The underlying condition generally suggests this entity, and FNA or surgical biopsy taken from the mass supports the diagnosis of EMH. If there is no known underlying condition, careful examination of a peripheral blood smear and then the nec- 
essary diagnostic tests including hemoglobin electrophoresis and bone marrow biopsy confirm the diagnosis. There is limited data about the detection of EMH using PET CT; thus far, only a few cases have been reported in patients with EMH [6]. We thus do not know the properties of the PET CT imaging of $\mathrm{EMH}$. SUV max value is generally low and the tissue appears normal. Underlying hematopoietic disorder may suggest $\mathrm{EMH}$, and a sampling of this tissue confirms the diagnosis. In our case, the CT scan showed a paravertebral mass, and FNA suggested EMH. However, dyspnea and fatigue development in the recent past and the history of heavy smoking required further evaluation. PET CT revealed a paravertebral mass with benign tumor properties. However, there was a surprise on PET, which revealed a small mass with very high SUV max value, suggesting a malignant tumor. Biopsy confirmed the non-small cell lung cancer.

\section{Conclusion}

EMH was detected as a benign-appearing mass on PET CT in a case with thalassemia intermedia. SUV max was very low in $\mathrm{EMH}$, which suggested a benign tumor. PET CT also showed a small malignant mass in our case, which could not be detected by CT scan.

\section{Conflict of interest statement}

None of the authors of this paper has a conflict of interest, including specific financial interests, relationships, and/or affiliations relevant to the subject matter or materials included.

\section{References}

1. Meo A, Cassinerio E, Castelli R, Bignamini D, Perego L, Cappellini MD. Effect of hydroxyurea on extramedullary haematopoiesis in thalassaemia intermedia: case reports and literature review. Int $\mathrm{J}$ Lab Hematol 2008;30:425-31. [CrossRef]

2. Galati MC, Raiola G, De Sanctis V, Arcuri V, Arcuri PP, Brachi S, Borsari G. Extramedullary haematopoiesis in beta thalassaemia--unusual presentations: case reports. Pediatr Endocrinol Rev 2008;6:140-3.

3. Debard A, Demasles S, Camdessanche JP, Duband S, Mohammedi R, Antoine JC. Dural localization of extramedullary hematopoiesis. Report of a case. J Neurol 2009;256:837-8. [CrossRef]

4. Chunduri S, Gaitonde S, Ciurea SO, Hoffman R, Rondelli D. Pulonary extramedullary hematopoiesis in patients with myelofibrosis undergoing allogeneic stem cell transplantation. Haematologica 2008;93:1593-5. [CrossRef]

5. Monce B, Hafedh J. Management of spinal cord compression caused by extramedullary hematopoiesis in beta-thalassemia. Inter Med 2008;47:1125-8. [CrossRef]

6. Masley C, Jacene HA, Holz A, Grand DJ, Wahl RL. Extramedullary hematopoiesis on F-18 FDG PET/CT in a case with metastatic colon carcinoma. Clin Nucl Med 2007;32:878-80. [CrossRef] 